\title{
KANDUNGAN ANTINUTRISI, LOGAM BERAT DAN CEMARAN BIOLOGIS TEPUNG BUAH Sonneratia spp DAN Rhizophora mucronata DARI POPULASI HUTAN MANGROVE DI KABUPATEN KUPANG
}

Antinutrient, heavy metal and biological contaminant content of Sonneratia spp and Rhizophora mucronata fruit flour from mangrove population growth in Kupang District

\author{
Ermi E. Koeslulat ${ }^{1}$, Sigit B. Prabawa ${ }^{2}$ \\ ${ }^{1}$ Kontributor Utama ${ }^{1}, 2$ Balai Penelitian dan Pengembangan Lingkungan Hidup dan Kehutanan Kupang \\ Jl. Alfons Nisnoni no. 7 (Belakang) Airnona, Kupang, NTT, Indonesia \\ email penulis korespondensi: erni.ekoes@yahoo.co.id
}

Tanggal diterima: 26 Agustus 2019, Tanggal direvisi: 29 Agustus 2019, Disetujui terbit: 25 November 2019

\begin{abstract}
Mangrove degradation tend to increase due to excessive human activity such as land conversion, wood extraction for construction and fuel wood and nonmetallic extraction. The utilization of fruit of mangroves-in certain limits- can be an alternative way to convert the destructive utilization into more environmentally friendly one. This study aims to determine three types of flour i.e Sonneratia spp fruit flesh flour (SFFF), Rhizophora mucronata fruit skin flour (RSFF); and Rhizophora fruit flesh flour (RFFF). Since the utilization of SFFF is more developed in community than RSFF and RFFF, the SFFF is examined more than the two next. The analysis was conducted at the Laboratory of Center for Agro-Based Industry and Laboratory of Study Center for Biopharmaca, Bogor Agricultural Institute. The examination of SFFF covered antinutrient content (tannin and cyanide acid (HCN)), heavy metal (Pb, Mn, Cu, $\mathrm{Hg}$ and As) and biological contaminants (total plate count, Escherichia coli, Bacillus cereus, Salmonella sp, mold and yeast). The examination of RSFF and RFFF covered only tannin as antinutrient and $\mathrm{Pb}, \mathrm{Mn}, \mathrm{Cu}, \mathrm{Hg}$ and $\mathrm{As}$ as heavy metals. The results showed that SFFF met the SNI Standards for tannin, HCN, Hg, As, E.coli, B. cereus, Salmonella sp, molds and yeasts while the Cu and Mn did not. RSFF and RFFF met the standards for tannin, $\mathrm{Hg}$ and As, while Pb, Cu dan Mn content did not. These content may be reduced by increasing the soaking and boiling time.
\end{abstract}

Keywords: fruit of mangrove, tannin, $\mathrm{HCN}, \mathrm{Pb}$, boiling

\begin{abstract}
ABSTRAK
Degradasi mangrove cenderung meningkat akibat aktivitas manusia yang berlebihan seperti konversi lahan, ekstraksi kayu untuk konstruksi dan kayu bakar dan kegiatan tambang non logam. Pemanfaatan buah mangrove dalam batas tertentu dapat menjadi salah satu alternatif untuk mengubah pemanfaatan yang merusak menjadi lebih ramah lingkungan. Penelitian ini bertujuan untuk mengetahui tiga jenis tepung yaitu tepung daging buah Sonneratia spp (SFFF), tepung kulit buah Rhizophora mucronata (RSFF); dan tepung daging buah Rhizophora (RFFF). Karena pemanfaatan SFFF lebih berkembang di masyarakat daripada RSFF dan RFFF, SFFF diteliti lebih dari dua berikutnya. Analisis dilakukan di Laboratorium Balai Besar Industri Agro dan Laboratorium Balai Studi Biofarmaka Institut Pertanian Bogor. Pemeriksaan SFFF meliputi kandungan antinutrien (tanin dan asam sianida $(\mathrm{HCN})$ ), logam berat $(\mathrm{Pb}, \mathrm{Mn}, \mathrm{Cu}, \mathrm{Hg}$ dan $\mathrm{As}$ ) dan kontaminan mikroba (angka lempeng total, Escherichia coli, Bacillus cereus, Salmonella sp, kapang dan ragi). Pemeriksaan RSFF dan RFFF hanya mencakup tanin sebagai antinutrien dan $\mathrm{Pb}, \mathrm{Mn}, \mathrm{Cu}, \mathrm{Hg}$ dan As sebagai logam berat. Hasil penelitian menunjukkan bahwa SFFF memenuhi Standar SNI untuk tannin, HCN, Hg, As, E.coli, B. cereus, Salmonella sp, kapang dan khamir sedangkan $\mathrm{Cu}$ dan Mn tidak. RSFF dan RFFF memenuhi standar tannin, $\mathrm{Hg}$ dan As, sedangkan kandungan $\mathrm{Pb}, \mathrm{Cu}$ dan $\mathrm{Mn}$ tidak. Kandungan yang melebihi ini diduga dapat dikurangi dengan meningkatkan waktu perendaman dan perebusan.
\end{abstract}

Kata kunci: buah mangrove, tanin, $\mathrm{HCN}, \mathrm{Pb}$, perebusan

\section{PENDAHULUAN}

Nusa Tenggara Timur (NTT) memiliki hutan mangrove seluas $40.614,11$ ha, namun sebagian besar telah mengalami kerusakan yaitu sebanyak $8.285,10$ ha atau 20,40\% (kategori rusak berat), 19.552,44 ha atau 48,14\% (kategori rusak ringan), dan $12.776,57$ ha atau $31,46 \%$ (kategori baik) (Balai Pengelolaan Hutan Mangrove Wilayah I, 2011). Kerusakan diantaranya disebabkan oleh aktivitas manusia 
yang berlebihan seperti konversi lahan, pengambilan kayu untuk konstruksi dan kayu bakar serta penambangan bahan galian bukan logam. Oleh karena itu, perlu adanya pengelolaan hutan mangrove yang baik, yang didalamnya terdapat pengalihan aktivitas manusia yang lebih ramah lingkungan sebagai sumber ekonomi. Pemanfaatan buah mangrove pada batas tertentu dapat menjadi alternatif kegiatan masyarakat yang dapat mendatangkan nilai ekonomi. Terdapat pengalaman pemanfaatan buah mangrove seperti jenis Bruguiera gymnorrhizha sebagai pengganti nasi saat masa paceklik, seperti di Kabupaten Lembata dan Rote Ndao (Hidayatullah, Raharjo, \& Ndolu, 2015), sedangkan jenis-jenis lain seperti Sonneratia spp dan Rhizophora mucronata belum pernah dimanfaatkan di masyarakat. Namun demikian, pemanfaatan Sonneratia spp dan Rhizophora mucronata telah berkembang di wilayah lain di Indonesia bahkan di berbagai negara, seperti pembuatan sirup, selai dan panganan lainnya (Jariyah, Widjanarko, Yunianta, Estiasih, \& Sopade, 2014; Purwaningsih, Salamah, Sukarno, \& Deskawati, 2013; Wiratno, Johan, \& Hamzah, 2017; Hardoko, Suprayitno, Puspitasari, \& Amalia, 2015; Suganthy \& Devi, 2016). Selain itu $R$. mucronata juga berpotensi menjadi pangan fungsional karena memiliki aktivitas biologis sebagai antidiabetik, antioksidan, antiinflamasi, antimikroba, anti-HIV, dan anktivitas antikolinesterase (Bibi et al., 2019) Kelemahan pemanfaatan buah $R$. mucronata adalah tidak dapat dikonsumsi secara langsung karena kandungan tanin yang tinggi, sedangkan buah Sonneratia spp dapat dikonsumsi langsung.

Uji coba penggunaan buah Sonneratia spp sebagai bahan baku panganan di Kabupaten Kupang telah dilakukan (Koeslulat, 2018; Koeslulat, Ndolu, Banani, \& Paidjo, 2017), sedangkan $R$. mucronata belum pernah dilakukan karena terbatasnya informasi terkait seberapa tinggi kandungan antinutrisi yang terdapat dalam buahnya. Kandungan antinutrisi perlu diketahui karena merupakan senyawa alami yang dapat mengganggu penyerapan nutrisi (Kumari \& Jain, 2012). Nurdiani, Firdaus, dan Prihanto (2012) menyatakan bahwa dalam ekstrak metanol buah $R$. mucronata terdapat alkaloid, tanin, flavonoid dan steroid Selain itu Chrissanty (2012) dan Muryati dan Nelfiyanti (2015) juga menyatakan adanya kandungan HCN dalam buah mangrove. Tanin dapat membentuk ikatan komplek dengan protein sehingga mengganggu aktivitas enzimenzim pencernaan (Muryati \& Nelfiyanti, 2015) sedangkan asam sianida (HCN) dalam bahan pangan pada umumnya berupa glukosida sianogenik yang sebenarnya tidak beracun, namun apabila bagian tanaman tersebut mengalami proses mekanis seperti diiris, direbus, dikukus, dimakan atau mengalami kerusakan dan menghasilkan $\mathrm{HCN}$ yang dalam bila termakan dalam dosis $0,5-3,5 \mathrm{mg} / \mathrm{kg}$ dapat mematikan (Muryati \& Nelfiyanti, 2015).

Selain kandungan antinutrisi, kandungan bahan berbahaya seperti logam berat dan kontaminan biologi perlu diketahui. Logam berat dalam tubuh akan berpengaruh negatif bagi proses fisiologis tubuh. Mangrove hidup di daerah pasang surut, yang dapat merupakan tempat pembuangan limbah dari industri maupun domestik. Kemampuannya untuk menyerap logam berat menjadikan pemeriksaan kandungan logam dari buah mangrove penting dilakukan. Menurut Amaliah, Samawi, dan Oka (2018) kemampuan untuk menyerap dan mengakumulasi logam berat berbeda untuk setiap spesies. Mobilitas logam berat dan konsentrasi logam berat antar organ tumbuhan seperti akar, cabang, daun juga berbeda dalam satu spesies.

Selain antinutrisi dan logam berat, cemaran biologis juga dapat menggangu fungsi tubuh. Cemaran biologis dapat masuk dalam bahan pangan melalui 3 cara yaitu bahan baku termasuk bahan pendukungnya, pekerja dan lingkungan tempat pengolahan bahan pangan. Mikroorganisme yang paling umum digunakan sebagai indikator adanya cemaran adalah 
Escherichia coli, Bacillus cereus dan Salmonella sp, kapang dan khamir.

Escherichia coli adalah mikroflora yang secara alami terdapat dalam saluran pencernaan manusia dan hewan. Namun bila jumlahnya berlebihan atau berada di luar saluran pencernaan dapat membahayakan karena dapat menyebabkan peradangan. E. coli dapat masuk ke dalam bahan pangan melalui air yang tercemar yang digunakan dalam proses pengolahan. Bacillus cereus termasuk dalam genus Gram-positif, bakteri anaerob fakultatif pembentuk endospora. Sporanya memiliki resistensi terhadap sejumlah kondisi merugikan yang menyebabkan organisme ini tersebar secara luas seperti di udara, tanah, dan air, serta pada material hewan dan tumbuhan. Keberadaannya terbanyak di tanah, namun bisa mencemari makanan dan dapat menimbulkan penyait diare dan muntah (Griffiths \& Schraft, 2017). Salmonella sp. adalah bakteri yang mampu menembus dinding usus dan masuk dalam peredaran darah. Bakteri ini merupakan penyebab demam tifoid (tifus). Bakteri ini dapat bersumber dari air yang tercemar oleh kotoran binatang atau manusia (Manyi-loh et al., 2016; Takal \& Quaye-ballard, 2018). Meskipun buah Sonneratia spp dan $R$. mucronata sendiri memiliki sifat antibakteri (Lutfiasari, Aminarti, \& Ajizah, 2017; Sungkar, Khanza, \& Pangestu, 2018), namun produk pangan dari buah mangrove tetap perlu diuji keamanannya. Selain cemaran berupa bakteri patogen, cemaran biologis dapat berupa jamur/kapang, ragi serta virus yang mampu mengubah bentuk fisik makanan yang tidak diinginkan, seperti tekstur, penampilan, bau dan rasa. Jumlah serta jenis mikroba tersebut dipengaruhi oleh suhu lingkungan, $\mathrm{pH}$, kadar air bahan pangan itu sendiri, dan dapat dikontrol dengan mengatur kondisi pengolahan seperti pembekuan makanan dan penambahan bahan pengawet (Saranraj \& Geetha, 2012).

Pemeriksaan terhadap kandungan antinutrisi (tanin dan $\mathrm{HCN})$, logam berat $(\mathrm{Pb}$, $\mathrm{Cu}, \mathrm{Hg}, \mathrm{As}$, dan $\mathrm{Mn}$ ), dan cemaran biologis ( $E$. coli, B. cereus dan Salmonella $\mathrm{sp)}$ dari tepung buah $R$. mucronata dan Sonneratia spp, diharapkan dapat sebagai dasar pengembangan pangan dari buah mangrove, teknik pemanfaatan buah, serta peningkatan produktivitas dan kualitas buah melalui rekayasa fisiologi tanaman dan perbaikan genetik tanaman.

\section{BAHAN DAN METODE}

\section{A. Lokasi dan bahan penelitian}

Sampel buah R.mucronata dan Sonneratia spp. diambil dari populasi hutan mangrove di Desa Pariti, Kabupaten Kupang. Pohon asal sampel buah diambil secara purposive sampling dari pohon Sonneratia spp dan $R$. mucronata, $\varnothing<30 \mathrm{~cm}$. Tingkat kematangan buah sedang karena tidak ditemukan buah yang matang di pohon karena jatuh dan terbawa arus air. Ukuran buah Sonneratia spp panjang $\pm 2 \mathrm{~cm}, \varnothing$ buah $3 \mathrm{~cm}$, sedangkan panjang buah $R$. mucronata $\pm 19 \mathrm{~cm}$ dan $\emptyset \pm 1 \mathrm{~cm}$. Pembuatan sampel tepung buah dilakukan di Laboratorium Silvikultur Balai Litbang Lingkungan Hidup dan Kehutanan Kupang. Pengujian tanin dilakukan di Laboratorium Pusat Studi Biofarmaka Institut Pertanian Bogor. Pengujian logam berat dilakukan di Balai Besar Industri Agro Bogor. Bahan uji berupa daging buah Sonneratia spp; kulit dan daging buah Rhizophora mucronata.

\section{B. Metode}

Pembuatan tepung Sonneratia spp mengikuti Koeslulat (2018), sedangkan tepung kulit dan daging buah $R$. mucronata dibuat dalam kondisi mentah karena belum ada dukungan literatur dan untuk mengetahui kandungan antinutrisi serta jumlah cemaran dalam bahan baku alaminya. Cara pengujian adalah sebagai berikut:

Tanin. Pengujian menggunakan metode titrasi (Monisa, Bintang, Safithri, \& Falah, 2016). Sebanyak 100 gram tepung diekstraksi dengan metode refluks dengan $1 \mathrm{~L}$ air selama 2 jam pada suhu $100^{\circ} \mathrm{C}$. Ekstrak disaring dan 
dikeringkan. Sebanyak 0,2 g ekstrak diambil dan dimasukkan dalam labu Erlenmeyer 250 $\mathrm{mL}$ yang sudah ditambahkan dengan air mendidih $5 \mathrm{~mL}$. Labu dipanaskan 30 menit, didiamkan selama beberapa menit dan dituang ke dalam labu takar $25 \mathrm{~mL}$ dengan menggunakan segumpal kapas sebagai penyaring. Residu yang tertinggal ditambahkan dengan air mendidih yang kemudian disaring lagi dengan kapas sampai esktrak tanin habis. Setelah selesai, cairan didinginkan dan ditambahkan dengan air sampai tanda batas. Larutan dipipet sebanyak 2,5 $\mathrm{mL}$ dan dimasukkan ke dalam labu takar $100 \mathrm{~mL}$, kemudian ditambahkan dengan 2,5 $\mathrm{mL}$ indigokarmin sulfonat LP dan air sampai tanda batas. Titrasi dengan $\mathrm{KMnO}_{4} 0,1 \mathrm{~N}$ hingga larutan berwarna kuning emas. Larutan blanko dibuat dengan prosedur yang sama tanpa contoh. Sebanyak $1 \mathrm{~mL} \mathrm{KMnO}_{4} 0,1 \mathrm{~N}$ setara dengan $0,004157 \mathrm{~g}$ tanin.

$\operatorname{Tanin}(\%)=\frac{\left(\mathrm{VKMnO}_{4 \text { sampel }}-\mathrm{VKMnO}_{4 \text { blankol }}\right) \times\left(\frac{0.004157}{1} \mathrm{~mL}\right)}{\text { bobot awal sampel }} \times 100 \%$

HCN. Pengujian mengikuti SNI 7622:2011 lampiran A.12 (Badan Standarisasi Nasional, 2011). Ditimbang 50 gram contoh, dimasukkan ke dalam labu didih, dan ditambahkan air suling $150 \mathrm{ml}$, ditutup dan dibiarkan selama 24 jam dan ditambahkan $10 \mathrm{ml}$ asam tartrat $10 \%$. Larutan didestilasi dan hasil destilasi ditampung dalam erlenmeyer berisi 10 $\mathrm{ml}$ larutan $\mathrm{NaOH} 40 \%$. Destilasi diakhiri setelah destilat mencapai $300 \mathrm{ml}$. Beberapa tetes larutan Kalium Iodida $10 \%$ ditambahkan dalam destilat dan dititrasi dengan AgNO3 0,1 N. Titrasi berakhir setelah larutan menjadi keruh kekuning-kuningan.

$$
\mathrm{HCN}(\%)=\frac{\mathrm{VAgNO}_{3}(\mathrm{ml}) \times \text { normalitas } \mathrm{AgNO}_{3}}{\text { berat sampel }(\mathrm{g})} \times 100 \%
$$

Logam Berat. Pengujian menurut SNI 01-2896-1998 (Badan Standarisasi Nasional, 1998b), kecuali As menurut SNI 01-4866-1998 (Badan Standarisasi Nasional, 1998a). Prinsip pengujian logam adalah dengan mengukur serapan logam yang terkandung dalam sejumlah tertentu contoh tepung yang telah didestruksi, baik dengan cara kering yaitu dengan pengabuan dalam tanur pada suhu $450^{\circ} \mathrm{C}$, maupun dengan basah dengan asam. Nilai absorbansi logam dapat diketahui dengan terlebih dahulu membuat kurva kalibrasi masing-masing logam larutan standar masingmasing logam dengan konsentrasi yang berbeda. Absorbansi larutan standar masing-masing diukur pada 293,3 nm (Pb); 279,5 nm (Mn), $324,7 \mathrm{~nm}(\mathrm{Cu}), 253,7 \mathrm{~nm}(\mathrm{Hg})$, dan 193,7 nm (As).

Angka Lempeng Total. Pengujian menurut ISO 4833:2003 (E), ISO 7218:2012 (International Organization for Standardization, 2003). Ditimbang $25 \mathrm{~g}$ contoh dan dimasukkan ke dalam erlenmeyer yang telah berisi $225 \mathrm{ml}$ larutan pengencer. Campuran dikocok hingga homogen. Dilakukan pengenceran agar tidak terlalu pekat dan terlalu encer, untuk mempermudah perhitungan koloni. Pada masing-masing labu pengenceran dipipet sebanyak $1 \mathrm{ml}$ ke dalam cawan petri steril secara duplo. Ke dalam setiap cawan petri tuangkan sebanyak $15 \mathrm{ml}$ media PCA yang telah dicairkan yang bersuhu $(45 \pm 1)^{\circ} \mathrm{C}$ dalam waktu 15 menit dari pengenceran pertama dan digoyangkan hingga contoh tercampur rata. Dibuat blanko dengan mencampur air pengencer dengan pembenihan untuk setiap contoh yang diperiksa. Campuran dalam cawan petri dibiarkan membeku dan cawan petri dimasukkan dalam lemari pengeram dan inkubasikan pada suhu $30^{\circ} \mathrm{C}$ selama 72 jam pada posisi terbalik. Pertumbuhan koloni dicatat setelah 48 jam. Angka lempeng total dalam $1 \mathrm{~g}$ contoh dengan mengalikan jumlah rata-rata koloni pada cawan petri dengan faktor pengenceran yang digunakan.

E. Coli. Pengujian dilakukan menurut BAM 2002 Chapter 4 (Feng, Weagant, \& Grant, Michael A. William, 2002). Sebanyak 25 gram contoh dimasukkan ke dalam wadah steril kemudian dilakukan uji pendugaan dengan melakukan pengenceran $10^{-1}$ hingga 
pengenceran $10^{-3}$ menggunakan larutan Buffered peptone water (BPW) 0,1\%. Dari masing-masing pengenceran dipipet $1 \mathrm{ml}$ ke dalam 3 seri tabung Lauryl Sulfate Tryptose Broth (LSTB) dan diinkubasi pada suhu $35^{\circ} \mathrm{C}$ selama 2 hari. Dilakukan isolasi dengan cara menginokulasikan ke dalam media Violet Red Bile Agar (VRBA) dan diinkubasi selama 18-24 jam pada suhu $35^{\circ} \mathrm{C}$. Koloni yang diduga E.coli berdiameter 2-3mm, berwarna hitam pada bagian pusat koloni diambil dan dipindahkan ke Plate Count Agar (PCA) miring lalu diinkubasi selama 18-24 jam pada suhu $35^{\circ} \mathrm{C}$. Kemudian dilakukan reaksi biokimia yaitu uji pembentukan indole dan uji methyl red (MR).

B. cereus. Pengujian dilakukan menurut AOAC 10ed 2005 point 17.8.01 (Chemists Association of Official Analytical, 2005). Ditimbang $50 \mathrm{~g}$ contoh ke dalam blender yang bersih dan steril. Tambahkan $450 \mathrm{ml}$ butterfield's phosphate-buffered dilution water (1:10) dan kocok selama 2 menit pada kecepatan tinggi (18.000-21.000 rpm), dan buat seri pengenceran dengan menggunakan larutan butterfield's phosphate-buffered dilution water (1:10). Diambil sebanyak $1 \mathrm{ml}$ larutan dari setiap tingkat pengenceran (larutan $10^{-1}, 10^{-2}$ dan $10^{-3}$ ) ke dalam tiga tabung trypticase soypolymyxin broth, kemudian diinkubasikan dalam inkubator pada suhu $30{ }^{\circ} \mathrm{C}$ selama (48 \pm 2) jam; dan diamati untuk melihat pertumbuhan B. cereus. Biakan dari tabung yang positif digores sedikit dan ditaruh ke dalam media MYP (Mannitol-egg yolk-polymyxin (MYP) agar dan inkubasi selama 48 jam pada suhu $30{ }^{\circ} \mathrm{C}$. Koloni yang koloni yang berwarna eosin merah muda dengan lechitinase positif diambil sebanyak 1 atau lebih koloni dan pindahkan ke media nutrien agar untuk konfirmasi B.cereus. Konfirmasi dilakukan dengan kultur campuran dan pemeriksaan mikroskopis dengan ciri berbentuk batang besar, gram positif, rantai pendek hingga panjang, spora berbentuk ellips, letaknya ditengah sampai sub terminal dan spora tersebut tidak menggembungkan sporangium.
Salmonella sp. Pengujian dilakukan menurut ISO 6579:2002 (E) (International Organization for Standardization, 2002). Tepung mangrove ditimbang sebanyak 25 gram dan dimasukkan ke dalam wadah steril. Kemudian dilakukan pengenceran $10^{-1}$ dan diinkubasi selama 24 jam dengan suhu $35^{\circ} \mathrm{C}$. Setelah itu, contoh yang diencerkan dengan mengambil $1 \mathrm{~mL}$ ke dalam media $10 \mathrm{ml}$ tetrationate broth (TTB) dan $0,1 \mathrm{~mL}$ ke dalam $10 \mathrm{~mL}$ ravaport vasilliadis (RV) dan diinkubasi selama 24 jam pada suhu $42^{\circ} \mathrm{C}$ untuk media RV dan $43^{\circ} \mathrm{C}$ untuk media TTB. Dilakukan isolasi masing-masing contoh dengan cara menginakolasikan ke dalam media hektoen enteric agar (HE), xylose lysine desoxycholate agar (XLD), dan bismuth sulfit agar (BSA) dan diinkubasi selama \pm 24 jam. Koloni Salmonella dicirikan dengan warna hijau kebiruan pada media HE, merah muda tanpa titik mengkilat pada media XLD dan abu-abu kehitaman pada media BSA. Kemudian dilakukan identifikasi dengan menginakolasikan koloni ke media triple sugar iron agar (TSIA) dan lysine iron agar (LIA) dengan cara menusukkan ke dasar media agar dan menggores pada media agar miring lalu diinkubasi selama 24 jam pada suhu $35^{\circ} \mathrm{C}$. Terbentuknya warna merah pada slant agar miring dan warna kuning pada bagian bawah media TSIA serta ungu pada slant agar miring dan warna ungu pada bagian bawah media LIA menunjukan contoh positif Salmonella.

Kapang, Khamir. Pengujian dilakukan menurut BAM 2001 Chapter 18 (Tournas, Stack, Philip B, Koch, \& Bandler, 2001). Sebanyak $25 \mathrm{~g}$ contoh dimasukkan ke dalam erlenmeyer yang telah berisi $225 \mathrm{~mL}$ larutan pengencer dan digoyangkan hingga. homogen. Dilakukan pengenceran hingga $10^{1}-10^{2}$ pengenceran. Dari masing-masing pengenceran di pipet sebanyak $1 \mathrm{~mL}$ dari masingmasing pencenceran ke dalam cawan petri steril secara duplo. Sebanyak 20 mL PDA dituangkan sampai dan cawan petri digoyangkan sehingga campuran merata. Pembenihan dibiarkan membeku dan diinkubasikan pada suhu (25 \pm 
1) ${ }^{\circ} \mathrm{C}$ selama 5 hari (tanpa dibalik). Hitung semua koloni kapang atau khamir mulai hari ketiga dengan menggunakan alat penghitung koloni. Rata-rata jumlah koloni dan kalikan dengan faktor pengenceran. Koloni kapang biasanya buram dan berbulu. Sedangkan koloni khamir berwarna putih dan licin (berbau asam). Hasilnya dinyatakan dalam jumlah kapang atau khamir per $\mathrm{g}$.

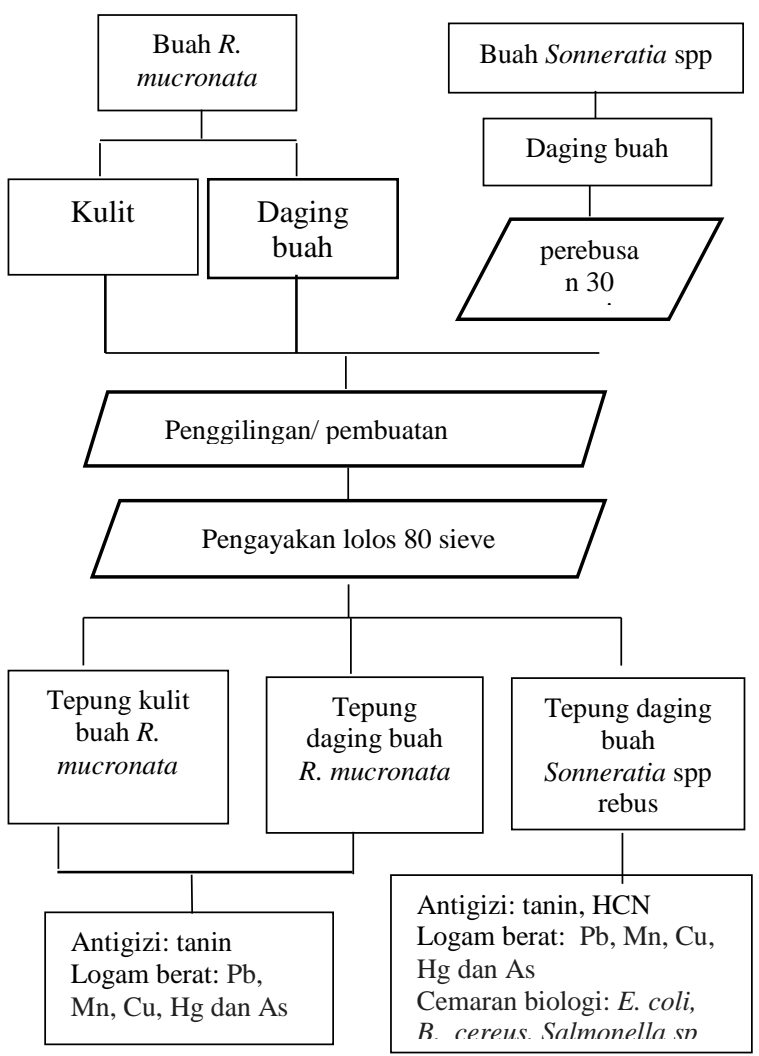

Gambar 1. Cara penelitian

\section{Analisis data}

Data ditabulasi dan hasilnya dibandingkan dengan SNI untuk tepung dan literaturnya yang sesuai. Hasil dijelaskan secara deskriptif.

\section{HASIL DAN PEMBAHASAN}

Kandungan tanin sampel disajikan pada Tabel 2. Tabel 2 menunjukkan bahwa kandungan tanin kulit dan daging buah R.mucronata mentah rata-rata berturut-turut adalah $0,12 \%$ dan $0,28 \%$. Kandungan tanin tepung daging buah Sonneratia spp yang sudah direbus adalah $0,26 \%$. Nilai-nilai tersebut cukup rendah, dibandingkan dengan jenis Bruguiera sp pada penelitian Muryati dan Subandriyo (2015), yang menyatakan bahwa kandungan tanin tepung buah tancang adalah $88,973 \mathrm{mg} / \mathrm{kg}$ atau $8,90 \%$. Belum ada standar kandungan tanin dalam bahan makanan, namun terdapat batas asupan Persyaratan/SNI tentang tanin dalam Standar Nasional Indonesia (SNI), yaitu batas aman berdasarkan ADI (Acceptable Daily Intake) dalam bahan makanan yaitu $560 \mathrm{mg} / \mathrm{kg}$ berat badan/hari (Muryati \& Subandriyo, 2015). Dengan demikian tepung dari kulit dan daging buah $R$. mucronata yang tidak direbus dan tepung daging buah Sonneratia spp yang telah direbus dapat dikonsumsi secara aman.

Meskipun aman dikonsumsi, secara sensorik, kue yang berasal dari buah Sonneratia spp masih memiliki rasa getir dan pahit (Koeslulat, 2018) sehingga kandungan 0,26\% harus diturunkan lagi untuk memberikan rasa yang lebih baik. Beberapa cara yang dapat dilakukan diantaranya dengan menambah waktu perebusan, penambahan bahan alkali seperti abu gosok dan perendaman di awal sebelum perebusan (Perdana, Soenardjo, \& Supriyantini, 2017; Soenardjo \& Supriyantini, 2017). Pada penelitian ini, peningkatan waktu perebusan akan meningkatkan biaya produksi yaitu konsumsi bahan bakar, sehingga perendaman lebih disarankan

Tabel 2. Kandungan tanin rata-rata tepung daging buah Sonneratia sp, tepung kulit buah R.mucronata dan tepung daging buah R.mucronata

\begin{tabular}{lc}
\hline Sampel & $\begin{array}{c}\text { Kandungan tanin (\%) } \\
\left(\mathbf{n}^{*}=\mathbf{2}\right)\end{array}$ \\
\hline $\begin{array}{l}\text { Daging buah Sonneratia } \\
\text { spp }\end{array}$ & 0,26 \\
$\begin{array}{l}\text { Kulit buah } \text { R.mucronata } \\
\text { Daging buah }\end{array}$ & 0,12 \\
\begin{tabular}{l} 
R.mucronata \\
\hline
\end{tabular} & 0,28 \\
\hline
\end{tabular}

$* \mathrm{n}=$ ulangan

Kandungan HCN dapat dlihat pada Tabel 3. 
Tabel 3. Kandungan HCN pada tepung daging buah Sonneratia spp

\begin{tabular}{lll}
\hline Perlakuan & $\begin{array}{l}\text { Hasil } \\
(\mathrm{mg} / \mathrm{kg})\end{array}$ & $\begin{array}{l}\text { Maks SNI }(\mathrm{mg} / \mathrm{Kg}) \\
\text { (Badan Standarisasi } \\
\text { Nasional, 1996) }\end{array}$ \\
\hline $\begin{array}{l}\text { Kontrol } \\
\text { (Tidak } \\
\text { direbus) }\end{array}$ & $<3^{*}$ & 40 \\
Direbus & $<3^{*}$ & 40 \\
\hline
\end{tabular}

$*_{\text {sensitivitas alat }} \geq 3 \mathrm{mg} / \mathrm{kg}$

Dari Tabel 3 diketahui bahwa kandungan HCN tepung buah Sonneratia spp baik yang tidak direbus maupun direbus, tergolong rendah, yaitu <3 mg/kg. Nilai ini lebih rendah dari kandungan HCN pada Bruguiera gymnorrhiza $3,38 \mathrm{mg} / \mathrm{kg}$ yang diteliti Sulistyawati et al. (2012) dan Muryati dan Nelfiyanti (2015) yaitu $8,05 \mathrm{mg} / \mathrm{kg}$. Dengan demikian, tepung daging buah Sonneratia spp tergolong aman untuk diolah menjadi panganan. Merujuk Food and Agriculture Organization/World Health Organization (2013), bahwa batas yang diijinkan untuk ubi kayu dan produknya adalah $<50 \mathrm{mg} / \mathrm{kg}$, maka konsumsi tepung daging buah Sonneratia spp aman untuk dikonsumsi.

Kandungan logam berat pada sampel disajikan pada Tabel 4.

Tabel 4. Kandungan logam berat pada sampel

\begin{tabular}{lcccc}
\hline Parameter & $\begin{array}{c}\text { Tepung daging } \\
\text { buah Sonneratia } \\
\text { spp } \\
(\mathrm{mg} / \mathrm{kg})\end{array}$ & $\begin{array}{c}\text { Tepung kulit buah } \\
\text { R.mucronata } \\
(\mathrm{mg} / \mathrm{kg})\end{array}$ & $\begin{array}{c}\text { Tepung daging } \\
\text { buah R.mucronata } \\
(\mathrm{mg} / \mathrm{kg})\end{array}$ & $\begin{array}{c}\text { Batas maksimum dalam bahan } \\
\text { pangan }(\mathrm{mg} / \mathrm{Kg})\end{array}$ \\
\hline Timbalan $(\mathrm{Pb})$ & 0,28 & $\mathbf{1 , 1 8}$ & $\mathbf{4 , 2 4}$ & $2009 \mathrm{~b})$ \\
Tembaga $(\mathrm{Cu})$ & $\mathbf{1 3 , 3}$ & $\mathbf{3 , 6 5}$ & $\mathbf{5 , 2 3}$ & 1,0 \\
Raksa $(\mathrm{Hg})$ & $<0,005$ & $<0,005$ & $<0,005$ & 10 \\
Arsen $(\mathrm{As})$ & $<0,003$ & $<0,003$ & $<0,003$ & 0,05 \\
Mangan $(\mathrm{Mn})$ & $\mathbf{1 0 , 1 3}$ & $\mathbf{1 4 , 9 9}$ & $\mathbf{2 0 , 3 1}$ & 0,05 \\
\hline
\end{tabular}

Tabel 4 menunjukkan bahwa untuk $\mathrm{Pb}$, hanya tepung daging buah Sonneratia spp yang direbus yang aman untuk dikonsumsi, sedangkan kandungan $\mathrm{Pb}$ pada tepung kulit dan daging buah R.mucronata melebihi standar yang disyaratkan. Hal ini bertentangan dengan pernyataan Paz-Alberto, Celestino, dan Sigua (2014) bahwa kemampuan menyerap $\mathrm{Pb}$ oleh Sonneratia spp lebih tinggi dari pada R.mucronata. Oleh karena itu, rendahnya kandungan $\mathrm{Pb}$ pada tepung buah Sonneratia spp diduga disebabkan proses perebusan yang tidak dilakukan pada $R$. mucronata. Kehadiran kandungan $\mathrm{Pb}$ pada buah diduga disebabkan adanya aktivitas pertanian di sekitar lokasi penelitian. Hidayatullah et al. (2015) menyatakan bahwa 76\% masyarakat Desa Pariti memiliki mata pencaharian sebagai petani, dan beberapa jenis pestisida dan pupuk mengandung
$\mathrm{Pb}$ dalam bahan aktifnya (Hartini, 2011). Penggunaan beberapa jenis pupuk ini dapat meningkatkan $\mathrm{Pb}$ di estuari.

Kandungan $\mathrm{Cu}$ pada semua tipe tepung buah melebihi batas maksimum yang disyaratkan. $\mathrm{Cu}$ pada tepung daging buah rebus Sonneratia spp jauh lebih tinggi $(13,3 \mathrm{mg} / \mathrm{Kg})$ dari tepung kulit $(3,65 \mathrm{mg} / \mathrm{Kg})$ dan daging $(5,23$ $\mathrm{mg} / \mathrm{Kg}$ ) buah mentah R.mucronata. Kecenderungan ini sejalan dengan Marchand, Fernandez, \& Moreton (2016) dan Hamzah \& Setiawan (2010) yang menyatakan bahwa Faktor Bioakumulasi (rasio konsentrasi logam berat pada bagian tanaman terhadap logam berat pada sedimen) jenis Sonneratia untuk logam $\mathrm{Cu}$ lebih tinggi dari pada R.mucronata. Selain itu, lebih tingginya kandungan $\mathrm{Cu}$ dibanding $\mathrm{Pb}$ pada jaringan buah ini disebabkan $\mathrm{Cu}$ merupakan logam esensial yang diperlukan 
untuk pertumbuhan mangrove (Marchand et al., 2016).

Kandungan $\mathrm{Hg}$ dan As semua tepung buah dinyatakan lebih rendah dari batas maksimum, yaitu $<0,005$ (Tabel 4). Hal ini berarti tepung ini aman untuk dikonsumsi. Rendahnya kandungan Hg pada buah ini sejalan dengan Qiu, Yu, Zhang, dan Wang (2011) dan Cordova, Dwi, Eftiah, dan Zamani (2017) yang menyatakan bahwa $\mathrm{Hg}$ lebih banyak terakumulasi di daun, sedangkan As banyak terakumulasi di akar (Mandal et al., 2019; Qiu et al., 2011). Hal ini juga dapat menggambarkan bahwa lokasi perairan masih belum tercemar.

Belum ada standar batas aman Mn dalam bahan pangan. Namun terdapat beberapa saran asupan yang cukup diantaranya 1,8-2,6 mg/hari (Marles, 2017). Jumlah ini juga dapat bervariasi tergantung oleh gaya hidup, jenis kelamin dan usia. Bila merujuk angka tersebut, kandungan Mn hasil penelitian ini tergolong tinggi. Hal ini diduga karena Faktor Bioakumulasi dan Faktor
Translokasi (rasio konsentrasi logam berat dalam bagian tanaman terhadap akar) Mn yang lebih tinggi dibanding logam lainnya seperti $\mathrm{Zn}$, $\mathrm{Cu}, \mathrm{Pb}, \mathrm{Ni}, \mathrm{Cr}, \mathrm{Co}, \mathrm{As}, \mathrm{Cd}$ dan $\mathrm{Hg}$ (Chowdhury et al., 2017) Selain itu, tingginya akumulasi Mn pada sedimen yang bersumber dari kegiatan pertanian di sekitar lokasi penelitian, dimana menurut Hidayatullah et al. (2015) mata pencaharian utama masyarakat Desa Pariti adalah bertani, dimana Mn merupakan unsur esensial utama yang dibutuhkan tanaman diperlukan untuk meningkatkan mutu fisiologi tanaman padi (Agustiansyah, 2017).

Tingginya kandungan Mn pada semua jenis tepung pada penelitian ini membuat konsumsi tepung daging buah Sonneratia spp, kulit dan daging buah R.mucronata ini tidak boleh melebihi berturut-turut 9,87 kg/hari, 6,67 $\mathrm{kg} / \mathrm{hari}$ dan $4,92 \mathrm{~kg} / \mathrm{hari}$. Selain itu, perlu dilakukan perbaikan pada proses pembuatan, seperti penambahan waktu perebusan atau perendaman.

Tabel 5. Cemaran biologis tepung buah Sonneratia spp mentah dan Sonneratia spp rebus

\begin{tabular}{lccc}
\hline $\begin{array}{l}\text { Parameter } \\
\text { (satuan) }\end{array}$ & $\begin{array}{c}\text { Tepung buah Sonneratia } \\
\text { spp mentah (kontrol) }\end{array}$ & $\begin{array}{c}\text { Tepung buah } \\
\text { Sonneratia spp rebus }\end{array}$ & $\begin{array}{c}\text { Batas maksimum (Badan Standardisasi } \\
\text { Nasional, 2009a) }\end{array}$ \\
\hline $\begin{array}{l}\text { Angka lempeng Total 30 }{ }^{\circ} \mathrm{C} \text { 72 jam } \\
\text { (koloni/gram) }\end{array}$ & $<10$ & $<10$ & $1 \times 10^{6}$ \\
Escherichia coli (AMP/gram) & $<3$ & $<3$ & 10 \\
Bacillus cereus (koloni/gram) & 0 & 0 & $<1 \times 10^{4}$ \\
Salmonella Sp. (koloni/25 gram) & Negatif & Negatif & - \\
Kapang (koloni/gram) & $<10$ & $<10$ & $1 \times 10^{4}$ \\
Khamir (koloni/gram) & $<10$ & $<10$ & $1 \times 10^{2}$
\end{tabular}

Dari Tabel 5 diketahui bahwa untuk tepung daging buah Sonneratia spp yang direbus dan tidak direbus (kontrol), semuanya tergolong aman untuk dikonsumsi karena mengandung cemaran biologis di bawah batas maksimum yang ditetapkan. Hal ini diduga disebabkan oleh karena adanya kandungan bahan aktif yang berperan sebagai antibakteri dalam biji dan daging buah Sonneratia spp yang mampu menghambat pertumbuhan bakteri E. coli, B. cereus, Salmonella sp dan jenis bakteri lainnya (Hossain et al., 2013; Yompakdee,
Thunyaharn, \& Phaechamud, 2012). Selain itu, proses pengambilan buah dari pohon, dilakukan dengan cara meminimalkan kontak dengan tanah dan air yang merupakan sumber B. cereus terbanyak (Mailia, Yudhistira, Pranoto, Rochdyanto, \& Rahayu, 2015). Lokasi pengambilan sampel yang berdekatan dengan pemukiman dan persawahan, dimana potensi buangan feces manusia, sapi atau babi lebih tinggi dan terakumulasi di daerah pantai. Lingkungan tempat tumbuh dan air yang digunakan di tempat pembuatan tepung juga 
diduga bebas dari bakteri patogen.

Jumlah kapang dan khamir pada penelitian ini <10 (Tabel 5), di bawah batas maksimum yang dipersyaratkan oleh SNI untuk tepung-tepungan. Sifat fisiko kimia tepung seperti rendahnya kadar air akibat proses pengeringan, kurang sesuai untuk pertumbuhan kapang dan khamir. Menurut Saranraj dan Geetha (2012) tahapan dalam pengolahan makanan dapat mengendalikan pertumbuhan mikroba patogen. Kondisi tepung Sonneratia spp yang kering karena melalui proses pemanasan dalam oven dan penyimpanan dalam wadah tertutup membuat tepung Sonneratia spp penelitian ini kurang sesuai untuk pertumbuhan jamur dan kapang.

\section{KESIMPULAN}

Tepung daging buah Sonneratia spp, tepung kulit dan daging buah R.mucronata dari populasi hutan mangrove di Kabupaten Kupang memenuhi standar SNI untuk parameter antinutrisi tanin dan $\mathrm{HCN}$, cemaran logam berat $\mathrm{Hg}$, As, cemaran biologis E.coli, B.cereus, Salmonella sp, kapang dan khamir. Kandungan $\mathrm{Pb}$ pada tepung kulit dan daging buah R.mucronata perlu diturunkan lagi dengan memperbaiki proses pengolahan agar memenuhi standar SNI. Penggunaan tepung daging buah Sonneratia spp, kulit dan daging buah R.mucronata hendaknya memperhatikan angka kecukupan asupan, terkait tingginya kandungan $\mathrm{Cu}$ dan $\mathrm{Mn}$.

\section{UCAPAN TERIMAKASIH}

Terimakasih kepada Balai Penelitian dan Pengembangan Lingkungan Hidup dan Kehutanan Kupang atas dukungan dana penelitian, Bapak Felipus Banani, Bapak Lamek Paidjo dan Bapak Bernadus Ndolu atas bantuan tenaga dalam pengumpulan data penelitian.

\section{DAFTAR PUSTAKA}

Agustiansyah. (2017). Pengaruh Pemberian Silika dan Mangan Terhadap Mutu Fisiologis Benih
Padi (Oryza sativa L.) yang Dihasilkan. Agrivigor, 10(1), 44-48.

Amaliah, Samawi, F., \& Oka, N. P. (2018). Kemampuan Jenis Tumbuhan Mangrove dalam Menyerap Logam Berat $\mathrm{Pb}$ (Timbal) dan $\mathrm{Cu}$ (Tembaga) di Muara Sungai Tallo. Journal Sains \& Teknologi, 18(3), 291-297.

Badan Standardisasi Nasional. (2009a). Batas Maksimum Cemaran Mikroba dalam Pangan. Standar Nasional Indonesia (SNI 7388:). Jakarta, Indonesia: Badan Standarisasi Nasional.

Badan Standardisasi Nasional. (2009b). Tepung Terigu Sebagai Bahan Makanan. SNI 3751:2009. Jakarta.

Badan Standarisasi Nasional. (1996). Tepung singkong. Standar Nasional Indonesia (SNI 01-299). Jakarta: Badan Standarisasi Nasional.

Badan Standarisasi Nasional. (1998a). Cara Uji Cemaran Arsen dalam Makanan (SNI 01486). Jakarta: Badan Standarisasi Nasional.

Badan Standarisasi Nasional. (1998b). Cara Uji Cemaran Logam dalam Makanan (SNI 01289). Jakarta: Badan Standarisasi Nasional.

Badan Standarisasi Nasional. (2011). Tepung Mocaf (SNI 01-762). Jakarta: Badan Standarisasi Nasional.

Balai Pengelolaan Hutan Mangrove Wilayah I. (2011). Statistik Pembangunan. Denpasar.

Bibi, S. N., Fawzi, M. M., Gokhan, Z., Rajesh, J., Nadeem, N., R, R. K. R., ... Pandian, S. K. (2019). Ethnopharmacology, Phythochemistry, and Global Distribution of Mangroves-A Compehensive Review. Marine Drugs, 17(231), 1-82.

Chemists Association of Official Analytical. (2005). Official Methods of Analysis of the Association of Official Analytical Chemists, Volume 18. The Association University of Wisconsin-Madison.

Chowdhury, R., Favas, P. J. C., Jonathan, M. P., Venkatachalam, P., Raja, P., \& Kumar, S. (2017). Bioremoval of trace metals from rhizosediment by mangrove plants in Indian Sundarban Wetland. Marine Pollution Bulletin, 124(2), 1078-1088. http://doi.org/10.1016/j.marpolbul.2017.01.0 47

Chrissanty, P. A. (2012). Penurunan Kadar Tanin pada Buah Mangrove Jenis Brugueira gymnorrhiza, Rhyzophora stylosa dan Avicennia marina untuk Diolah Menjadi 
Tepung Mangrove. Jurnal Industria, 1(1), 31-39.

Cordova, M. R., Dwi, F., Eftiah, M., \& Zamani, N. P. (2017). Ability of Mangrove Apple as Mercury Bioindicator. Omni-Akuatika, 13(2), 137-143.

Feng, P., Weagant, S. D., \& Grant, Michael A. William, B. (2002). BAM Chapter 4: Enumeration of Escherichia coli and the Coliform Bacteria. Bacteriological Analytical Manual (BAM). Food and Drug Administration.

Food and Agriculture Organization/World Health Organization. (2013). Proposed Draft Maximum Levels for Hydrocyanic Acid in Cassava and Cassava Products. Rome.

Griffiths, M. W., \& Schraft, H. (2017). Chapter 20 Bacillus cereus Food Poisoning. In C. E. R. Dodd, T. Aldsworth, R. A. Stein, D. O. Cliver, \& H. P. Riemann (Eds.), Foodborne Diseases (Third Edition) (Third Edit, pp. 395-405). Academic Press. http://doi.org/https://doi.org/10.1016/B978-012-385007-2.00020-6

Hamzah, F., \& Setiawan, A. (2010). Akumulasi Logam Berat $\mathrm{Pb}, \mathrm{Cu}$, dan $\mathrm{Zn}$ di Hutan Mangrove Muara Angke, Jakarta Utara. Jurnal Ilmu Dan Teknologi Kelautan Tropis, 2(2), 41-52.

Handayanta, E. (2002). Optimalisasi Penggunaan Daun Ubikayu sebagai Pakan Ternak Ruminansia. Cakratani, XVII(2), 41-48.

Hardoko, Suprayitno, E., Puspitasari, Y. E., \& Amalia, R. (2015). Study of Ripe Rhizophora mucronata Fruit Flour as Functional Food for Antidiabetic. International Food Research Journal, 22(3), 953-959.

Hartini, E. (2011). Kadar Plumbum (Pb) dalam Umbi Bawang Merah di Kecamatan Kersana Kabupaten Brebes. Jurnal Visikes, 10(1), 6975 .

Hidayatullah, M., Raharjo, S. A. S., \& Ndolu, B. (2015). Prosiding Diskusi Ilmiah. In A. M. Solahudin, B. D. Prasetyo, H. B. Santoso, \& S. B. Prabawa (Eds.), Sinergitas Peneliti, Widyaswara dan Penyuluh Kehutanan dalam Desiminiasi Informasi Guna Mendukung Pembangunan Lingkungan Hidup dan Kehutanan NTT (pp. 41-52). Kupang: Balai Penelitian dan Pengembangan Lingkungan Hidup dan Kehutanan Kupang.

Hossain, S. ., Basar, M. ., Rokeya, B., Arif, K. M. ., Sultana, M. ., \& Rahman, M. . (2013). Evaluation of Antioxidant, Antidiabetic and Antibacterial Activities of The Fruit of
Sonneratia apetala (Buch.-Ham.). Oriental Pharmacy and Experimental Medicine, 13(1), 95-102.

International Organization for Standardization. (2002). ISO 6579 Microbiology of food and animal feeding stuffs - Horizontal method for the detection of Salmonella spp. (4th ed., Vol. 2002). Switzerland: International Organization for Standardization.

International Organization for Standardization. (2003). International Standard ISO 4833 Microbiology of food and animal feeding stuffs - Horizontal method for the enumeration of microorganisms - Colonycount technique at $30{ }^{\circ} \mathrm{C}$ (3rd ed., Vol. 2003). Geneva: The International Organization for Standardization.

Jariyah, Widjanarko, S. ., Yunianta, Estiasih, T., \& Sopade, P. (2014). Pasting Properties Mixtures of Mangrove Fruit Flour (Sonneratia caseolaris) and Starches. International Food Research Journal, 21(6), 2161-2167.

Koeslulat, E. E. (2018). Seminar nasional teknologi dan inovasi industri tahun 2018. In N. Rahmi, L. Indriati, S. Hamdi, D. M. Amaliyah, R. Y. Lestari, E. Setiawati, ... M. L. Rharjo (Eds.), Peran Teknologi dan Inovasi Berbasis Sumber Daya Alam Lokal untuk Meningkatkan Daya Saing Industri Global (pp. 65-71). Banjarbaru: Balai Riset dan Standarisasi Industri Banjarbaru, Badan Penelitian dan Pengembangan Industri Kementerian Perindustrian.

Koeslulat, E. E., Ndolu, B., Banani, F., \& Paidjo, L. (2017). Kajian Potensi Jenis-jenis Mangrove sebagai Sumber Pangan Alternatif di Nusa Tenggara Timur. Kupang.

Kumari, M., \& Jain, S. (2012). Tannin: An Antinutrient with Positive Effect to Manage Diabetes. Research Journal of Recent Sciences, 1(12), 1-8.

Lutfiasari, N., Aminarti, S., \& Ajizah, A. (2017). Pengaruh Pemberian Infusa Buah Rambai (Sonneratia caseolaris) terhadap Pertumbuhan Bakteri Escherichia coli secara in Vitro. In M. A. Soendjoto, Dharmono, \& M. K. Riefani (Eds.), Jilid 1. Potensi, Peluang, dan Tantangan Pengelolaan (pp. 255-259). Banjarmasin: Lambung Mangkurat University Press.

MacFarlane, G. R., Koller, C. E., \& Blomberg, S. P. (2007). Accumulation and partitioning of heavy metals in mangroves: A synthesis of field-based studies. Chemosphere, 69(9), 1454-1464. 
http://doi.org/https://doi.org/10.1016/j.chemo sphere.2007.04.059

Mailia, R., Yudhistira, B., Pranoto, Y., Rochdyanto, S., \& Rahayu, E. S. (2015). Ketahanan Panas Cemaran Escherichia coli, Staphylococcus aureus, Bacillus cereus dan Bakteri Pembentuk Spora yang Diisolasi dari Proses Pembuatan Tahu di Sudagaran Yogyakarta. Agritech, 35(3), 300-308.

Mandal, S. K., Ray, R., González, A. G., Pokrovsky, O. S., Mavromatis, V., \& Jana, T. K. (2019). Accumulation, transport and toxicity of arsenic in the Sundarbans mangrove, India. Geoderma, 354(July), 113891. http://doi.org/10.1016/j.geoderma.2019.1138 91

Manyi-loh, C. E., Mamphweli, S. N., Meyer, E. L., Makaka, G., Simon, M., \& Okoh, A. I. (2016). An Overview of the Control of Bacterial Pathogens in Cattle Manure. International Journal of Enviromental Research and Public Health, 13, 1-27. http://doi.org/10.3390/ijerph13090843

Marchand, C., Fernandez, J. M., \& Moreton, B. (2016). Trace metal geochemistry in mangrove sediments and their transfer to mangrove plants (New Caledonia). Science of the Total Environment, 562, 216-227. http://doi.org/10.1016/j.scitotenv.2016.03.20 6

Marles, R. J. (2017). Mineral nutrient composition of vegetables, fruits and grains: The context of reports of apparent historical declines. Journal of Food Composition and Analysis, 56, 93-103. http://doi.org/10.1016/j.jfca.2016.11.012

Monisa, F. S., Bintang, M., Safithri, M., \& Falah, S. (2016). Potensi Ekstrak Tanin Daun dan Kulit Batang Surian sebagai Penghambat $\alpha$ Glukosidase ( Tannin Extract Potential of Surian Leaf and Bark as $\alpha$-Glucosidase Inhibitor ). Jurnal Ilmu Teknologi Кауи Tropis, 14(2), 156-164.

Muryati, \& Nelfiyanti. (2015). Pemisahan Tanin dan HCN secara Ekstraksi Dingin pada Pengolahan Tepung Buah Mangrove untuk Substitusi Industri Pangan. Jurnal Riset Teknologi Pencegahan Pencemaran Industri, 6(1), 9-16.

Muryati, \& Subandriyo. (2015). Pemisahan Tanin dan HCN pada Pengolahan Tepung Buah Mangrove untuk Substitusi Bahan Baku Industri Pangan. In Seminar Nasional

Sulistyawati, Wigyanto, \& Sri kumalaningsih. (2012). Produksi Tepung Buah Lindur (Bruguiera gymnorrhizha Lamk.) Rendah
Pangan Lokal, Bisnis dan Eko-Industri (pp. 35-42).

Nurdiani, R., Firdaus, M., \& Prihanto, A. A. (2012). Phytochemical Screening and Antibacterial Activity of Methanol Extract of Mangrove Plant (Rhyzophora mucronata) from Porong River Estuary. Journal Basic Science and Technology, 1(2), 27-29.

Paz-Alberto, A. M., Celestino, A. B., \& Sigua, G. C. (2014). Phytoremediation of $\mathrm{Pb}$ in the Sediment of a Mangrove Ecosystem. Journal of Soils and Sediments, 14(1), 251-258. http://doi.org/10.1007/s11368-013-0752-9

Perdana, Y. S., Soenardjo, N., \& Supriyantini, E. (2017). Pengaruh Kadar Abu Gosok selama Perebusan dan Lama Perendaman Air terhadap Kadar Tanin Buah dan Tepung Mangrove (Avicennia marina). Journal of Marine Research, 1(2), 226-234.

Purwaningsih, S., Salamah, E., Sukarno, A. Y. P., \& Deskawati, E. (2013). Aktivitas Antioksidan dari Buah Mangrove (Rhizophora mucronata Lamk.) pada Suhu yang Berbeda. Jurnal Pengolahan Hasil Perikanan Indonesia, 16(3), 199-206.

Qiu, Y., Yu, K., Zhang, G., \& Wang, W. (2011). Accumulation and Partitioning of Seven Trace Metals in Mangroves and Sediment Cores from Three Estuarine Wetlands of Hainan Island, China. Journal of Hazardous Materials, 190(1), 631-638. http://doi.org/10.1016/j.jhazmat.2011.03.091

Saranraj, P., \& Geetha, M. (2012). Microbial Spoilage of Bakery Products and Its Control by Preservatives. International Journal of Pharmaceutical \& Biological Archive, 3(1), 38-48. http://doi.org/10.1016/S03781097(02)01207-7

Soenardjo, N., \& Supriyantini, E. (2017). Analisis Kadar Tanin Dalam Buah Mangrove Avicennia marina Dengan Perebusan Dan Lama Perendaman Air Yang Berbeda. Jurnal Kelautan Tropis, 20(2), 90. http://doi.org/10.14710/jkt.v20i2.1701

Suganthy, N., \& Devi, K. P. (2016). Nutritional Evaluation of Asiatic Mangrove Rhizophora Mucronata - Its Proximate Composition, Amino Acid Profiles and Physico-Chemical Properties. International Journal of Pharmaceutical Sciences and Research, 7(6), 2537-2545.

http://doi.org/10.13040/IJPSR.09758232.7(6).2537-45

Tanin dan HCN sebagai Bahan Pangan Alternatif. Jurnal Teknologi Pertanian, 13(3), 187-198. 
Sungkar, O. F., Khanza, S., \& Pangestu, R. A. (2018). Aktivitas Antibakteri Bedak yang Diperkaya dengan Konsentrasi Ekstrak Buah (Rhizophora mucronata). Jurnal Teknologi Pangan, 2(2), 135-141-141. http://doi.org/10.14710/jtp.2.2.135-141

Takal, J. K., \& Quaye-ballard, J. A. (2018). Bacteriological Contamination of Groundwater in Relation to Septic Tanks Location in Ashanti Region, Ghana. Cogent Environmental Science, 4(1), 1-11. http://doi.org/10.1080/23311843.2018.15561 97

Tournas, V., Stack, M. E., Philip B, M., Koch, H. A., \& Bandler, R. (2001). BAM Chapter 18:
Yeasts, Molds and Mycotoxins (8th ed.). Food and Drug Administration.

Wiratno, A. S., Johan, V. S., \& Hamzah, F. (2017). Pemanfaatan Buah Pedada (Sonneratia caseolaris) dalam Pembuatan Minuman Instan. JOM Faperta Universitas Riau, 4(1), $1-13$.

Yompakdee, C., Thunyaharn, S., \& Phaechamud, T. (2012). Bactericidal Activity of Methanol Extracts of Crabapple Mangrove Tree (Sonneratia caseolaris Linn.) Against MultiDrug Resistant Pathogens. Indian Journal of Pharmaceutical Sciences, 74(3), 230-236. http://doi.org/https://www.ncbi.nlm.nih.gov/p mc/articles/PMC3574533/?report=classic 